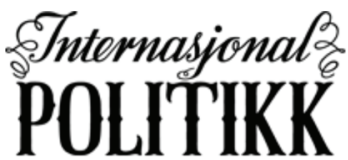 \\ SKANDINAVISK TIDSSKRIFT \\ FOR INTERNASIONALE STUDIER
}

Årgang 78, Nummer 4, side 523-534, 2020, ISSN 1891-1757, www.tidsskriftet-ip.no, Publisert desember 2020

FOKUS: NORGE, NORDOMRÅDENE OG UTENRIKSPOLITIKK

\section{Den «nye supermakten»: Hva vil Kina i Arktis?}

\author{
Anders Christoffer Edstrøm \\ Nordområdesenteret ved Handelshøgskolen Nord universitet, Norge \\ Iselin Stensdal og Gørild Heggelund \\ Fridtjof Nansens institutt, Norge
}

\begin{abstract}
Sammendrag
Kina har de senere årene fått en sterkere stemme i internasjonal politikk og har rettet oppmerksomhet og interesse mot nordområdene og mulighetene som finnes der. Inntredenen i regionen av en voksende supermakt har ikke gått upåaktet hen og har reist en rekke spørsmål blant de arktiske landene. Mange har fremmet ulike syn på og spekulasjoner om Kinas handlinger og retorikk i Arktis, og felles for disse er at de ønsker å forstå Kinas intensjoner. Denne artikkelen presenterer Kinas arktiske politikkutforming, hvordan Kina presenterer sine interesser i Arktis, og beskriver viktige kinesiske handlingsområder i Arktis. Artikkelen forsøker å svare på spørsmålene: Hvordan ser Kinas interesser i nordområdene ut i dag, og hva kan vi forvente av fremtidig kinesisk aktivitet i nord? Avslutningsvis reflekterer vi over betydningen dette kan ha for Norge.
\end{abstract}

Nøkkelord: nordområdene • kinesiske interesser • energi • transport • miljø og klima

\footnotetext{
^Kontaktinformasjon: Anders Christoffer Edstrøm, e-post: anders.c.edstrom@nord.no

(C2020 Anders Christoffer Edstrøm, Iselin Stensdal og Gørild Heggelund. This is an Open Access article distributed under the terms of the Creative Commons Attribution 4.0 International License (http://creativecommons.org/licenses/by/4.0/), allowing third parties to copy and redistribute the material in any medium or format and to remix, transform, and build upon the material for any purpose, even commercially, provided the original work is properly cited and states its license. Citation: Edstrom, A. C., Stensdal, I. E Heggelund, G. (2020). Den «nye supermakten»: Hva vil Kina i Arktis? Internasjonal Politikk, 78(4), 523-534. http://dx.doi.org/10.23865/intpol.v78.2477
} 


\section{Introduksjon ${ }^{\mathrm{I}}$}

Arktis opplever store og raske endringer på områder som klima, politikk og samfunn. I løpet av de ni årene som har gått siden vi fikk vår forrige stortingsmelding om nordområdene, har regionen fått økende internasjonal interesse og betydning. Kina, verdens mest folkerike land og en stigende supermakt, har etablert seg som en relativt ny aktør i Arktis. Allerede i 1925 undertegnet Kina Svalbardtraktaten, men så fulgte flere tiår uten noen videre kinesisk aktivitet i Arktis. Landets forskningsaktivitet i regionen begynte i 1990-årene, fulgt av åpningen av den kinesiske forskningsstasjonen i Ny-Ålesund på Svalbard i 2004. Et skille kan merkes i 2007. Da uttrykte Kina et ønske om permanent observatørstatus til Arktisk råd (Sørensen \& Klimenko, 2017, s. 5). Observatørstatus i Arktis råd i 2013 var en milepæl for Kina. Kina har fått en mer tydelig rolle internasjonalt under president Xi Jinping og publiserte i januar 2018 sin offisielle arktiske policy.

Kinas omtale av eget land som en «nær-arktisk stat» har vært kilde til spekulasjoner om Kinas ambisjoner i Arktis. For eksempel henvendte den amerikanske utenriksministeren Michael R. Pompeo seg i mai 2019 under ministermøtet i Arktisk råd i Rovaniemi direkte til Kina og kritiserte Kinas forsøk på opprettelse av en tredje kategori av arktiske stater (Pompeo, 2019). Andre kritiske røster til Kinas engasjement i Arktis ser mørkt på landets interesse for naturressurser i fremtiden. ${ }^{2}$

Når et av verdens største og mektigste land ikler seg en arktisk identitet og ønsker en større rolle i regionen, gjør de arktiske statene lurt i å finne best mulig måte håndtere den nye interessen på. Norge har inntil relativt nylig hatt et stort Russland liggende mellom seg og kinesisk aktivitet, men i nordområdene kan vi i økende grad måtte forholde oss til Kina i våre nærområder.

Med denne artikkelen vil vi bidra med faktabasert kunnskap om Kina i Arktis. Hvem utformer kinesisk arktispolitikk? Hva sier Kina selv at det ønsker i Arktis, og hva kan kinesiske aktiviteter i Arktis si om kinesisk interesse? Vi tar for oss disse spørsmålene, og knytter dem til slutt til hvilken betydning de har for Norge. Fordi Norge er både en energi- og en skipsfartnasjon, samt fordi det har vært noe aktivitet på disse områdene, vier vi disse to sidene av interessen størst oppmerksomhet. Gjennomgangen av både offisielle uttalelser og kinesisk aktivitet mener vi viser en $ø k t$ interesse i Arktis sammenliknet med for 15 år siden. Likevel er vår konklusjon at

\footnotetext{
${ }^{1}$ Forfatterne ønsker å takke fagfellen for gode kommentarer, og Nordland fylkeskommune for prosjektmidler som har gjort arbeidet med Kina mulig. Vi vil også takke redaktør Andreas Østhagen for å ha gitt oss denne muligheten og professor Frode Mellemvik og andre gode kollegaer for kommentarer og innspill til artikkelen.

${ }^{2}$ Enkelte observatører har poengtert at Kina en dag vil kunne inneha en militær kapasitet i Arktis. Militærfaglige vurderinger ligger utenfor det som er søkelyset i denne artikkelen. La oss likevel bemerke at Henrik Stålhane Hiim den 27. august 2020 under «Lytring Bodø: Blir det Kinas århundre nå?», en debatt i regi av Nord universitet og Nordlandsforskning, sa at den kinesiske marinen, så vidt ham bekjent, aldri har vært nord for polarsirkelen.
} 
forventningene og bekymringene så langt har oversteget Kinas faktiske engasjement i regionen.

\section{Arktispolitikk i Kina - hvordan blir den til?}

Kinesisk politikkutforming har ofte et langsiktig perspektiv og er preget av innspill fra forskjellige departementer og deres interesser. Arktispolitikken er intet unntak. Det lå en omfattende prosess bak det arktiske policydokumentet fra 2018. Vi forfatterne hørte fra kinesiske kollegaer og kilder i flere år før den ble lansert, at dette policydokumentet var underveis. At dokumentet ikke kom før i 2018, illustrerer at Arktis ikke er Kinas nærområde, og at det territorielt ikke har høyeste prioritet. Hadde Arktis vært førsteprioritet for Kina, ville myndighetene ha utarbeidet en policy flere år tidligere. Derimot har den gradvis økende interessen tillatt kinesiske myndigheter å inkludere og koordinere innspill fra mange parter.

State Council, Kinas regjering, opprettet allerede i 2011 en koordineringsmekanisme for arktiske anliggender, som samler 19 departementer og etater (Xu, 2017). Det er særlig det kinesiske utenriksdepartementet (Ministry of Foreign Affairs, MFA) som er viktig i Kinas arktispolitikk. MFAs retts- og avtaleavdeling forbereder offisielle uttalelser om Arktis, koordinerer deltakelse i Arktisk råd og representerer Kina i bilaterale og multilaterale arktismøter. MFA var ansvarlig for å koordinere arbeidet og innspillene til arktispolicyen. MFAs spesialutsending til Arktis, Gao Feng, har også tidligere vært spesialutsending til klima, og han har også vært hovedforhandler for Kina i klimaforhandlingene (UNFCCC). Videre er State Oceanic Administration (SOA) et viktig organ under Departementet for naturressurser (Ministry of Natural Resources) ${ }^{3}$. SOA lager utkast og forslag til arktispolitikk og er tilsynsorgan for overordnede arktiske aktiviteter. Både Chinese Arctic and Antarctic Administration (CAA) i Beijing med Polar Research Institute of China (PRIC) i Shanghai, ansvarlige for Kinas polarforskning, rapporterer til SOA. SOA er også leder av den rådgivende komiteen for polarforskning, som Departementet for vitenskap og teknologi (Ministry of Science and Technology, MOST) etablerte i 1994. I denne rådgivende komiteen er 16 departementer og institusjoner representert. Et kjennetegn ved kinesisk politikkutforming er at det internt gjerne kan være ulike politiske oppfatninger og uenigheter og dermed forhandlinger og diskusjoner innad, men at når politikken blir bestemt, er det konsensus utad (Lieberthal \& Lampton, 1992). Med ledergrupper og komiteer med representanter fra ulike deler av byråkratiet legges det opp til meningsutvekslinger, selv om vi på utsiden kun får vite resultatet, ikke noe om diskusjonsprosessen som ledet frem til det. Ut over departementer og byråkratiet har flere forskningsinstitutter og universiteter med polarforskning bidratt med

\footnotetext{
${ }^{3}$ Under en omorganisering i byråkratiet i 2018 ble SOAs innlemmelse under Departementet for naturressurser bestemt, men det er fortsatt ikke klart hvilke praktiske konsekvenser dette vil ha.
} 
rapportering og har hatt mulighet til å påvirke Kinas arktispolitikk. Kina styres etter prinsippet om "vitenskapelig syn på utvikling» ("scientific outlook on development»). Dette er ikke kun retorikk, prinsippet er likestilt med marxistisk-leninistisk tankegods i Kommunistpartiet (Deng, 2012). I praksis betyr det at forslag basert på forskning og vitenskap tillegges stor vekt i politikkutformingen i Kina. Det er etablerte kanaler mellom forskningsinstitusjoner og tenketanker og myndigheter for innspill til politikkutforming basert på forskningsprosjekter, som dermed når politiske beslutningstakere (Wübbeke, 2013; Li, 2017). Videre er provinser viktige i mange politiske beslutninger, og de har en god del autonomi og kan til en viss grad operere uavhengig av sentralmyndighetene. Provinsguvernørene har for eksempel samme hierarkiske posisjon som ministre. Subnasjonale myndigheter, som provinsmyndigheter som er interessert $\mathrm{i}$ internasjonalt og arktisk samarbeid, kan etablere dette. ${ }^{4}$

\section{Kinas arktiske policydokument}

I januar 2018 publiserte kinesiske myndigheter et arktisk policydokument (white paper) som beskrev Kinas nasjonale interesser, prioriteringer og tilnærminger i Arktis (State Council, 2018). Dette var den første skriftlige gjengivelsen av hvilke saksområder den kinesiske staten vektlegger i nord. Den viderefører tidligere kinesiske uttalte interesser og prioriteringer i Arktis og inneholder ikke grunnleggende nye posisjoner eller prioriteringer (MFA, 2015, 2017). Policydokumentet sammenfatter Kinas interesser og posisjoner for landets engasjement i Arktis og tegner et mer sammenhengende bilde av kinesisk interesse for regionen. I sitt arktiske policydokument uttrykker Kina respekt for de arktiske statenes territorielle suverenitet i Arktis, for internasjonal lovgivning og internasjonale avtaler. Det heter også at Kina ønsker å bidra i regionen samt fremme sine rettigheter. Dokumentet vektlegger en rekke områder av interesse for Kina: arktisk forskning og klima og miljø, shipping, ressursutvikling, fiskeri, turisme, bærekraftig arktisk styring og fred og stabilitet. Det uttalte målet for Kina er å ivareta alle staters og det internasjonale samfunnets interesser i Arktis samt å fremme bærekraftig utvikling. Oppsummert sier policydokumentet at landet har fire ønsker: å forstå Arktis, å beskytte Arktis, å utvikle Arktis og å delta i politikkutforming for Arktis.

Policydokumentet presenterer miljøvern og klimaendringer i Arktis som hoveddriverne bak Kinas arktiske engasjement. Kina har vært aktiv innen forskning over tid, og landets konkrete engasjement i Arktis har hovedsakelig vært rettet mot vitenskapelige ekspedisjoner og klimaforskning. Den økende bevisstheten i Kina om klimarisiko og sårbarhet i landet har medført større oppmerksomhet rundt klimatiske endringer i Arktis, og på hvordan disse påvirker Kina. Den arktiske oppvarmingen forårsaker ekstreme værhendelser i Kina samt påvirker nedbørsmønster og

\footnotetext{
${ }^{4}$ Vårt fremste norske eksempel er Nordland fylkeskommunes samarbeid med Zhejiang-provinsen.
} 
temperaturøkning (Zhang \& Yang, 2015; Wang, Sun, Hu, Tan \& Zeng, 2012). Klimaforskningen har særlig bidratt til å forme Kinas arktiske klimaagenda (Heggelund \& Han, 2020). Med så mye av policydokumentet viet forskning, miljøvern og klimaendringer, forskningsstasjon på Svalbard, et nybygget auroraobservatorium på Island samt et nytt forskningsfartøy med isbryterkapasitet kan vi forvente at forskningssporet er noe kinesiske myndigheter vil satse videre på.

\section{Aktivitet $\mathrm{i}$ internasjonale fora}

Kina fremholder landets ønske om å delta aktivt i utformingen av arktiske samstyringsregimer. Policydokumentet fremhever Kinas respekt for de arktiske statenes territorielle suverenitet, og det understreker viktigheten av at næringsaktivitet skal foregå i henhold til internasjonal og nasjonal lov. Kina oppfordrer egne aktører til å overholde gjeldende lover. Kina ønsker en plass ved bordet som aktør innen arktisk politikkutforming og har allerede engasjert seg i flere internasjonale fora.

I policydokumentet vektlegges det gjeldende internasjonale $\mathrm{FN}$-systemet, ved Den internasjonale havrettskonvensionen (UN Convention on Law of the Sea, UNCLOS), klimakonvensjon (UN Convention on Climate Change, UNFCCC) og Den internasjonale sjøfartsorganisasjonen (International Maritime Organization, IMO) som systemer Kina ønsker å støtte. Internasjonale avtaler som Svalbardtraktaten og Parisavtalen trekkes også frem. Kinas klimaengasjement under klimakonvensjonen, og også utenfor, har økt det siste tiåret. Kina deltok aktivt under forhandlingene av Polarkoden - lovgivningen som regulerer maritim ferdsel i polområdene. Som innehaver av verdens største fiskeflåte (Sala et al., 2018) er Kina opptatt av fiskeri, og Beijing ble som en partner i avtalen også med på forhandlingene da man skulle skape et nytt regime som regulerer fisket i arktisk internasjonalt farvann. De andre partnerne var Canada, Danmark, EU, Island, Japan, Norge, Russland, Sør-Korea og USA (Government of Canada, 2018).

Som observatør til Arktisk råd har Kina deltatt på regjeringsmøter, møter med seniorrepresentanter (Senior Arctic Officials, SAO-møter) og i arbeidsgrupper som i stor grad er rettet mot å forstå og bevare Arktis. Det er særlig i arbeidsgruppemøtene for Program for beskyttelse av det marine miljø (PAME), Det arktiske miljøovervåkingsprogrammet (AMAP) og Programmet for bevaring av arktisk fauna og flora (CAFF) kinesere har deltatt. Kina har nominert en rekke eksperter til disse arbeidsgruppene, og mye tyder på at Kina vil fortsette å nominere eksperter i fremtiden (Rottem \& Skedsmo, 2018, s. 15).

At Kina er mer aktivt internasjonalt og er med på å utforme nye internasjonale regler, har vi sett på mange områder de siste årene. Det er ikke unikt for det arktiske engasjementet. Som en av to stormakter er det ikke unaturlig at Kina også engasjerer seg mer i fora relatert til Arktis, og at landet sterkere fremmer sine interesser. Kina er klar på de arktiske statenes suverenitet og ikke-arktiske staters rettigheter i regionen, som havrettens uskyldige gjennomfart. Vi anser det som sannsynlig at Kina også i 
fremtiden vil være en aktivt deltakende part i forhandlinger om temaer som berører landets interesser, som klima, sjøfart og energi. Og det er nettopp innen sjøfart og energi vi har sett mest kinesisk aktivitet i Arktis til dags dato.

\section{Energi- og transportinteresser i Arktis}

Det har vært forventninger til det økonomiske potensialet knyttet til ressursutvinning og sjøtransport i Arktis i kinesiske rapporter og artikler (Moe \& Stokke, 2019a). Antallet realiserte energiprosjekter i Arktis hvor Kina er en partner, er dog sterkt begrenset. Det samme er kinesiske innslag i konstruksjon av infrastruktur og transport langs Den nordlige sjørute (Northern Sea Route, NSR). Yamal LNG og Arctic LNG 2 er de eneste virkelig betydningsfulle realiserte kinesiske petroleumsprosjektene i Arktis. Disse prosjektene har også betydning for utviklingen av NSR.

Kinas posisjon i verden fører til at interessen for Arktis trolig oppleves som større for de arktiske landene, enn den egentlig oppleves i Kina (Bertelsen \& Gallucci, 2016). Etter som isen smelter i Arktis, vil kommersiell navigasion i nordområdene muliggjøres og forenkles. Nordøstpassasjen fra Asia til Europa samt Nordvestpassasjen fra Asia til Amerika er to av rutene som kan bli aktuelle i fremtiden. Transporttiden mellom Asia og Europa vil potensielt kunne kortes ned med mellom 30 og 40 prosent via Arktis (Sun, 2018). Kina har fattet interesse for mulighetene som ligger i de arktiske transportrutene, har formelt inkludert disse i Belt and Road Initiative (BRI) og har i sitt Arktis-policydokument eksplisitt uttrykt ønske om sammen med partene å skape en polar silkevei (State Council, 2018). BRI, lansert i 2013, utgjør en av Kinas viktigste utenrikspolicyer og har som mål å opprette økonomiske korridorer over land og hav og å bringe markeder i Eurasia, Afrika og Europa sammen ved å investere i infrastruktur, og den vil inkludere mer enn 60 land (Swaine, 2015). Initiativet omfatter både harde og myke typer infrastruktur, som havner, jernbaner, økonomisk samarbeid og styrking av mellomfolkelige bånd (State Council, 2017).

Som vi har sett, vil Arktis kunne være en kilde til ressurser Kina trenger, og utvikling av NSR kan fungere som et vern samt som diversifisering mot uønskede hendelser langs de tradisjonelle og lange maritime transportrutene mellom Kina og markedene (Bertelsen \& Gallucci, 2016). Dette er videre en alternativ rute en stormakt som Kina kan ta seg råd til å pleie, vurderer forfatterne. Oppfatningen av ønsket om å diversifisere sine maritime transportruter til å gå gjennom Arktis deles av Brady (2020). Hun sier at Kina er spesielt bekymret for hendelser i Malakkastredet. Gjennom dette smale stredet passerer hele 85 prosent av Kinas maritime handel. En hendelse her vil kunne få stor økonomisk betydning for Kina. Per i dag er ikke NSR et godt alternativ.

Kinesiske selskaper oppfordres til å seile via NSR, og det kinesiske selskapet COSCO gjennomførte i henholdsvis 2017 og 2018 tolv og åtte arktiske kommersielle seilaser. Sammenliknet med Malakka er dette minimalt. Silkeveifondet, en av de store finansieringskildene bak BRI og medeier i Yamal LNG, har også investert 
tungt $i$ et russiskbasert maritimt fraktselskap kalt Maritime Arctic Transport. Dette selskapet vil gjennomføre transport i Arktis året rundt (Brady, 2020).

Yamal LNG utgjør foreløpig majoriteten av den kinesiske maritime aktiviteten ved at det er kinesiske eierinteresser i 14 av de 15 isbrytende LNG-transportskipene levert fra Sør-Korea (Moe \& Stokke, 2019a). Det er giennom uttalelser, publiseringer og handlinger klart at Kina ønsker å utvikle NSR. Kina har tatt konkrete steg for å utvikle ruten, men er ikke interessert for enhver pris. Mye tyder på at Kina har inntatt en forsiktig fremgangsmåte i utviklingen av ruten. Blant annet har Kina gitt uttrykk for at det ønsker mer å si over sjøruten før det investerer tungt i den, noe Russland har avslått (Moe \& Stokke, 2019b). Per i dag har den store utviklingen latt vente på seg, og sammenliknet med den tradisjonelle sjøruten mellom Kina og Europa er trafikken i Arktis marginal.

Med spesiell vektlegging av olje- og gassprosjekter i Arktis påpeker Weidacher Hsiung (2016) at interessen for petroleumsressursene i Arktis virker beskjeden, siden antallet slike store prosjekter i nordområdene er lavt. Før energiprisene falt i 2014, var det mye snakk om et rush nordover for de arktiske ressursene (Koivurova \& Kopra, 2020, s. 26). Dette rushet har i stor grad uteblitt. Ifølge Loe og kollegaer (Loe, Fjærtoft, Swanson \& Jakobsen, 2014, s. 18) vil Kina foruten diversifisering ha få insentiver for olje- og gassinvesteringer og transport langs NSR dersom kostnadene i Arktis er betydelig høyere enn andre steder.

På bakgrunn av en rekke russiske lovendringer som skulle legge til rette for et slikt arktisk flytende gassprosjekt på Yamal, fikk Novatek tilslaget i 2010. Dette var det samme året som Novatek klarte å sende et stort lasteskip med kondensat fra Murmansk til den asiatiske stillehavsregionen og levert til China National Offshore Oil Corporation (CNOOC) (Novatek, 2010). Yamal LNG er et enormt landbasert flytende gassprosjekt med en estimert kostnadsramme på 27 milliarder dollar. Dagens eierstruktur sto klar i september 2015, og størstedelen av prosjektet (50,1 prosent) eies av det børsnoterte russiske selskapet Novatek. Videre har franske Total og CNOOC 20 prosent hver, og det kinesiske Silkeveifondet kjøpte de resterende 9,9 prosent i 2015 (Novatek, 2015). Foruten kinesisk eierskap i prosjektet har Kina gjennom finansinstitusjoner som Export-Import Bank of China og China Development Bank gitt store lån på til sammen 12 milliarder dollar til prosjektet (Yamal LNG, 2016).

Novatek har begynt konstruksjonen av et søsterprosjekt kalt Arctic LNG 2. Dette prosjektet er på mange måter likheter med Yamal LNG, har en kostnadsramme på 21 milliarder dollar og har en rekke internasjonale partnere. Novatek har beholdt en eierandel på 60 prosent, mens både franske Total og kinesiske CNPC og CNOOC valgte å bli med på prosjektet med 10 prosent eierskap. I tillegg eier japanske Mitsui og JOGMEC som nye partnere til sammen 10 prosent av prosjektet (Humpert, 2020; Novatek, 2020). Partnerne i Yamal LNG har med andre ord valgt å fortsette med nye samarbeid og har også tiltrukket seg nye partnere. Nestleder Qin Weizhong i China National Petroleum Corporation (CNPC) har uttalt at Yamal LNG bidrar til landets energisikkerhet (Xu, 2018). 


\section{Hvordan kan vi forstå dagens situasjon?}

Relevant for dagens situasjon og Kinas fremtidige aktiviteter i Arktis er boken International Arctic Petroleum Cooperation. Her har en bred gruppe norske og russiske forskere laget tre scenarioer for den fremtidige utviklingen av olje- og gassressurser i Barentshavet, og som også har en overføringsverdi til andre regioner i Arktis (Bourmistrov et al., 2015). Forskerne introduserte en oversikt over tolv variabler med avgjørende betydning for fremtidig petroleumsaktivitet. Variablene har i denne artikkelen blitt tilpasset for å dekke kinesiske investeringer i spesielt det russiske Arktis: nivå på tilgjengelig arktisk teknologi, forventede fremtidige gasspriser, forventede fremtidige oljepriser, utbygging av prosjekter i naboregioner, mengden olje funnet, mengden gass funnet, vekst i Asia, grad av russisk orientering mot Asia, ukonvensjonelle energiprosjekter utenfor USA, russisk-kinesiske relasjoner, russiske og kinesiske relasjoner med vesten og utviklingen av et sterkt globalt klimaregime.

I denne sammenhengen er det interessant å se på oljeletingen på det islandske Dreki-feltet, som ligger i islandsk farvann mellom Island og Jan Mayen. Prosjektlisensen ble gitt i 2014 og var eiet 60 prosent av kinesiske CNOOC, 25 prosent av norske Petoro og 15 prosent av islandske Eykon Energy (Offshore Magazine, 2014). I januar 2018 kom nyheten om at CNOOC og Petoro hadde trukket seg fra prosjektet. Grunnen til avgjørelsen ble oppgitt å være for høye kostnader og risiko i prosjektet (Iceland Magazine, 2018). Med andre ord er dette et kinesisk energiprosjekt i Arktis som er lagt på is på grunn av økonomien i prosjektet.

Videre har Russland store energiforekomster på land i Arktis, og landbasert petroleumsteknologi er godt kjent for både Russland og Kina. De to landene har også utviklet store russiske forekomster av petroleum på land utenfor den arktiske sonen nær grensen til Kina, for eksempel gassprosjektet Power of Siberia (Cohen, 2019). Prosjektet kostet 55 milliarder dollar og skal levere 38 milliarder kubikkmeter gass i rørledning til Kina årlig i 30 år. Det kan se ut som om forholdene per i dag ikke ligger til rette for å bygge ut offshoreprosjekter, men at det bygges på land. Det er vanskelig å si noe konkret om fremtiden, men dersom forutsetningene for petroleumsprosjekter i arktiske havområder - herunder teknologiske og økonomiske - skulle forbedre seg, vil Kina muligens være godt posisjonert for å delta i utviklingen.

Med dagens svake energipriser, få nærliggende energiprosjekter, dårlig samarbeidsklima mellom Kina/Russland og vestlige partnere, vestlige sanksjoner mot Russland innen petroleumsteknologi og et tiltakende global oppmerksomhet på klima og miljø er det forståelig at vi i dag ikke ser en overflod av kinesisk petroleumsaktivitet i arktiske havområder.

\section{Oppsummering og implikasjoner for Norge}

Artikkelen har sett på Kinas interesser i nordområdene i dag, og på hva vi kan forvente av fremtidig kinesisk aktivitet i nord. Vi konkluderer med at Kina har hatt 
en voksende tilstedeværelse i Arktis og har konkrete interesser i regionen. Særlig har transport og energi vist seg å være områder hvor Kina har uttrykt interesse. Likevel er aktiviteten på begge disse områdene forholdsvis lav. Per i dag ser vi få konkrete kinesiske arktiske prosjekter, og vi har også sett avslutning av prosjekter grunnet kostnadsnivå. Om antallet prosjekter skyldes lav interesse, dårlig kommersielt grunnlag under nåværende forutsetninger eller andre faktorer, er vanskelig å konkludere helt sikkert. Rushet mot Arktis man så for seg på høye energipriser før 2014, har latt vente på seg, og Kinas samarbeid med Novatek i Yamalo-Nenetsregionen fremstår som det store eksemplet på kinesiske arktiske energiinvesteringer. Utvikling av Den nordlige sjørute vil kunne få store konsekvenser for Nord-Norge og Barentsregionen. Kirkenes er for eksempel særdeles godt plassert langs sjøruten og har potensialet til å bli en viktig omlastningshavn på europeisk side. Potensielt kan fremtidige aktiviteter i nord ta seg opp i takt med økende klimaendringer og et oppvarmet Arktis.

Som et lite land i verden, men som en stor arktisk nasjon, kan Kinas nærvær i nordområdene by på både muligheter og utfordringer for Norge. Miljø og klima presenteres giennom retorikk og antall prosjekter som hovedkomponenter i Kinas arktispolitikk, med mål om særlig å forstå de biologiske og klimatiske forholdene i regionen. Forskning er en viktig inngangsport til Arktis for Kina og legitimerer kinesisk tilstedeværelse og deltakelse i arktiske anliggender. Arktisk råds arbeid er nært knyttet til Kinas egne prioriteringer for miljø og klima og sammenfaller med Kinas nasjonale interesser og mål på disse områdene. Kinesiske myndigheter er opptatt av tilstedeværelse i Arktis, og observatørstatus i Arktisk råd er viktig i så måte.

Norge arbeider allerede nært med Kina på energi, klima og miljøspørsmål, som gir et godt utgangspunkt for videre samarbeid i Arktis. Gjennom samarbeidsprosjekter med Norge har Kina styrket sin ekspertise innen kvikksølvforskning det siste tiåret, spesielt når det gjelder kvikksølvutslipp. Kinas ekspertise kan være relevant for samarbeid i Arktisk råd om kvikksølv i Arktis, noe som også kan gi synergier mellom det innenlandske arbeidet med kvikksølv i Kina og kvikksølvutfordringene i Arktis.

Kina har uttalte interesser i Arktis, og for Norge og de andre arktiske landene er det sannsynlig at Kina vil være en arktisk aktør også i fremtiden. Vi ser en økende tendens til internasjonalisering, rivalisering og geopolitisk spill i Arktis mellom USA og Russland, der Kinas arktiske nærvær er en katalysator. Sannsynligvis er ikke dette i Kinas interesse. Til tross for et ønske om økt tilstedeværelse og samarbeid i Arktis synes andre utenriks- og sikkerhetspolitiske områder viktigere, som utviklingen $\mathrm{i}$ Sør-Kina-havet. Det vil være i Norges interesse å balansere forholdet til stormaktene diplomatisk, slik at konflikter ikke bremser en bærekraftig utvikling av nordområdene.

Vi behøver å utvikle mer kunnskap om Kinas interesser i Arktis, og om konsekvensene disse kan få for Norge. En scenariobasert fremgangsmåte som tar for seg investeringer og utvikling under ulike forutsetninger, vil være et nyttig bidrag til vår felles forståelse. 


\section{Om forfatterne}

Anders Christoffer Edstrøm jobber som rådgiver ved Nordområdesenteret ved Handelshøgskolen Nord universitet. Han har en mastergrad i økonomi og administrasjon med fordypning i energiledelse fra Nord universitet, med studieopphold i Russland og Kina.

Iselin Stensdal jobber som forsker ved Fridtjof Nansens institutt. Der jobber hun med Kinas energi, klima og miljøpolitikk. Et annet av hennes fagfelt er kinesiske interesser for Arktis. Hun har også mastergrad i kinastudier fra Universitetet i Oslo (2010).

Gørild Heggelund er seniorforsker ved Fridtjof Nansens institutt. Heggelund forsker på Kinas miljø-, energi- og klimapolitikk samt Kina i Arktis. Heggelund jobbet for $\mathrm{FN}$ og har bodd i Kina i mange år, hun snakker flytende kinesisk og har studert ved Peking University. Hun har doktorgrad (Doctor Artium) i Kinastudier ved Universitetet i Oslo.

\section{Referanser}

Bertelsen, R. \& Gallucci, V. (2016). The return of China, post-Cold War Russia, and the Arctic: Changes on land and at sea. Marine Policy, 72, 240-245. https://doi.org/10.1016/j.marpol.2016.04.034

Bourmistrov, A., Mellemvik, F., Bambulyak, A., Gudmestad, O., Øverland, I. \& Zolotukhin, A. (2015). International Arctic petroleum cooperation (s. 11-21). London, England: Routledge.

Brady, A.-M. (2020). China's interest in Arctic shipping. Insight Magazine. Hentet 24.juni 2020 fra https:// www.amcham-shanghai.org/en/article/insight-magazine-chinas-interest-arctic-shipping

Cohen, A. (2019). The strategic upside behind Russia's $\$ 55$ billion 'power of Siberia' pipeline to China. Forbes. Hentet 28. september 2020 fra https:/www.forbes.com/sites/arielcohen/2019/12/06/is-there-strengthbehind-russia-and-chinas-new-power-of-siberia-pipeline $/$ ?sh $=\mathrm{c} 77 \mathrm{c} 3301 \mathrm{fafc}$

Deng, Y. (2012). Amendments reflect CPC's resolve. China Daily. Hentet 16.06.20 fra http://www.chinadaily. com.cn/china/2013npc/2012-11/15/content_16261593.htm

Government of Canada. (2018). International agreement to prevent unregulated high seas fisheries in the central Arctic Ocean. Hentet 23. juni 2020 fra https://www.dfo-mpo.gc.ca/international/arctic-arctique-eng.htm

Heggelund, G. \& Han, C. (2020). China's climate policy: Does an Arctic dimension exist? I S. V. Rottem \& I. F. Soltvedt (Red.), Arctic governance: Norway, Russia and Asia (Bind 3, kap. 12). London, England: Bloomsbury.

Humpert, M. (2018, 11. september). China launches domestically-built «Xue Long 2» icebreaker. High North News. Hentet 18. juni 2020 fra https://www.highnorthnews.com/en/china-launches-domestically-builtxue-long-2-icebreaker

Humpert, M. (2020, 16. april). Construction of Novatek's Arctic LNG 2 project ahead of schedule. High North News. Hentet 24. juni 2020 fra https:/www.highnorthnews.com/en/construction-novateks-arctic-lng-2project-ahead-schedule

Iceland Magazine. (2018, 23. januar). Oil exploration in Icelandic waters comes to an end: Too expensive and too risky. Iceland Magazine. Hentet 28. september 2020 fra https://icelandmag.is/article/oil-explorationicelandic-waters-comes-end-too-expensive-and-too-risky

Koivurova, T. \& Kopra, S. (2020). Chinese policy and presence in the Arctic (s. 26). Leiden: Brill.

$\mathrm{Li}, \mathrm{C}$. (2017). The power of ideas. The rising influence of thinkers and think tanks in China. London: World Scientific Publishing Co.

Lieberthal, K. G. \& Lampton, D. M. (Red.) (1992). Bureaucracy, politics, and decision making in post-Mao China. Berkeley, CA: University of California Press. 


\section{Den «nye supermakten»}

Loe, J., Fjærtoft, D., Swanson, P. \& Jakobsen, E. (2014). Arctic business scenarios 2020. Menon Economics. Hentet fra https://www.menon.no/wp-content/uploads/27arctic-business-scenarios-2020.pdf

Ministry of Foreign Affairs (MFA). (2015). Keynote speech by Vice Foreign Minister Zhang Ming at the China country session of the third Arctic Circle assembly in Oct 2015. Hovedtale ved den tredje Arctic Circlekonferansen 2015, Reykjavik. Hentet 3. oktober 2020 fra http://www.fmprc.gov.cn/mfa_eng/wjbxw/ t1306858.shtml

Ministry of Foreign Affairs (MFA). (2017). 汪洋: 中国秉承尊重、合作、可持续三大政策理念参与北极事务 (Wang Yang: China adheres to the three policy concepts of respect, cooperation and sustainability to participate in the Arctic affairs). På kinesisk. Hentet 3. oktober 2020 fra http://www.fmprc.gov.cn/web/zyxw/t1449926. shtml

Moe, A. \& Stokke, O. S. (2019a). Asian countries and Arctic shipping: Policies, interests and footprints on governance. Arctic Review on Law and Politics, 10, 24-52. https://doi.org/10.23865/arctic.v10.1374

Moe, A. \& Stokke, O. S. (2019b). China and Arctic shipping: Policies, interests and engagement. I E. I. Safronova (Red.), China in world and regional politics (history and modernity). (Utg. XXIV). Moskva: Institute of Far Eastern Studies, Russian Academy of Sciences (IFES RAS).

Novatek. (2010, 6. september). NOVATEK delivers stable gas condensate to CNOOC via Northern Sea Route [Pressemelding]. Hentet 24. juni 2020 fra http://www.novatek.ru/en/investors/events/archive/index. php?id_4=117\&afrom_4=01.01.201

Novatek. (2015, 17. desember). NOVATEK and China's Silk Road Fund sign binding definitive agreements [Pressemelding]. Hentet 24. juni 2020 fra http://www.novatek.ru/en/investors/events/archive/index. php?id_4=1056\&afrom_4=12.08.20

Novatek. (2020). Arctic LNG 2 Ice-class Tanker Fleet Formation Completed [Pressemelding]. Hentet 25. november $2020 \mathrm{fra} \mathrm{http://www.novatek.ru/en/business/arctic-lng/}$

Offshore Magazine. (2014). CNOOC starts preparation work to explore for oil and gas offshore Iceland. Offshore Magazine. Hentet 28. september 2020 fra https:/www.offshore-mag.com/business-briefs/company-news/ article/16781049/cnooc-starts-preparation-work-to-explore-for-oil-and-gas-offshore-iceland

Pompeo, M. R. (2019, 6. mai). Looking North: Sharpening America's Arctic focus. Innlegg på ministermøtet i Arktisk råd 2019, Rovaniemi. Hentet 3. oktober 2020 fra https://www.state.gov/looking-north-sharpeningamericas-arctic-focus/

Rottem, S.V. \& Skedsmo, P.W. (2018). Observatørenes rolle i Arktisk råd (Rapport utarbeidet av Fridtjof Nansens Institutt for Utenriksdepartementet).

Sala, E., Mayorga, J., Costello, C., Kroodsma, D., Palomares, M., Pauly, D., ... Zeller, D. (2018). The economics of fishing the high seas. Science Advances, 4(6), eaat2504. https://doi.org/10.1126/sciadv.aat2504

State Council. (2017, 20. juni). Full text of the vision for maritime cooperation under the belt and road initiative [Myndighetspublikasjon].Hentet 24.juni 2020 fra http://english.www.gov.cn/archive/publications/2017/06/20/ content_281475691873460.htm

State Council. (2018). Full text: China's Arctic policy [Myndighetspublikasjon]. Hentet 23. juni 2020 fra http:// english.www.gov.cn/archive/white_paper/2018/01/26/content_281476026660336.htm

Sun, Y. (2018). The Northern Sea Route: The myth of Sino-Russian cooperation (Rapport). Hentet 28. september 2020 fra https://www.stimson.org/2018/northern-sea-route/

Swaine, M. (2015). Chinese views and commentary on the "one belt, one road». China Leadership Monitor, (47), 2-3. Hentet fra https://www.hoover.org/research/chinese-views-and-commentary-one-belt-one-road

Sørensen, C. \& Klimenko, E. (2017). Emerging Chinese-Russian cooperation in the Arctic. Possibilities and constraints (SIPRI Policy Paper nr. 46, s. 5). Stockholm International Peace Research Institute. Hentet 28. september fra https:/www.sipri.org/sites/default/files/2017-06/emerging-chinese-russian-cooperation-arctic.pdf

USGS. (2008, 23. juli). USGS release: 90 billion barrels of oil and 1,670 trillion cubic feet of natural gas assessed in the Arctic (Lydfil. 7/23/2008 1:00:00 PM). Hentet 17. juni 2020 fra https://archive.usgs.gov/archive/sites/ www.usgs.gov/newsroom/article.asp-ID=1980.html

Wang, X., Sun, Z., Hu, B., Tan,Y. \& Zeng, G. (2012). Relationship between Arctic sea ice thickness distribution and climate of China. Acta Meteorologica Sinica, 26(2), 189-204. https://doi.org/10.1007/s13351-0120205-1

Weidacher Hsiung, C. (2016). China and Arctic energy: Drivers and limitations. The Polar fournal, 6(2), 243-258. https://doi.org/10.1080/2154896x.2016.1241486

Wübbeke, J. (2013). China's climate change expert community - principles, mechanisms and influence. Fournal of Contemporary China, 22(82), 712-731. 
Xu, X. (2018, 12. desember). Yamal LNG project reaches full production capacity. Xinhua. Hentet 28. September 2020 fra http://www.xinhuanet.com/english/2018-12/12/c_137666821_2.htm

$\mathrm{Xu}, \mathrm{H}$. (2017). Arctic governance and China's participation. Fournal of Boundary and Ocean Studies, 2(2).

Yamal LNG. (2016). Yamal LNG signed loan agreements with the export-import bank of China and the China development bank [Pressemelding]. Hentet 7. oktober fra http://www.novatek.ru/common/upload/ doc/2016_04_29_press_release_Chinese_banks_FA_(ENG).pdf

Zhang, P. \& Yang, J. (2015). Changes in the Arctic and China's participation in Arctic governance. I L. Lunde, J.Yang \& I. Stensdal (Red.), Asian countries and the Arctic future. Singapore: World Scientific Publishing.

\begin{abstract}
English
The 'New Superpower': What Does China Want in the Arctic?

In recent years, China has gained a stronger voice in international politics and has turned its attention and interest to the High North and the opportunities that exist there. The entry into the region of a growing superpower has not gone unnoticed, and has raised a number of questions among the Arctic states. Many observers have put forward different views and speculations about China's actions and rhetoric in the Arctic, and what they have in common is that they want to understand China's intentions. This article introduces China's Arctic policy-making, how China formulates its interests in the Arctic, and describes key areas of action in the Arctic. What do China's interests in the High North look like today? In conclusion, we reflect on the significance this may have for Norway.
\end{abstract}

Keywords: High North · Chinese interests • energy • transport • environment and climate 